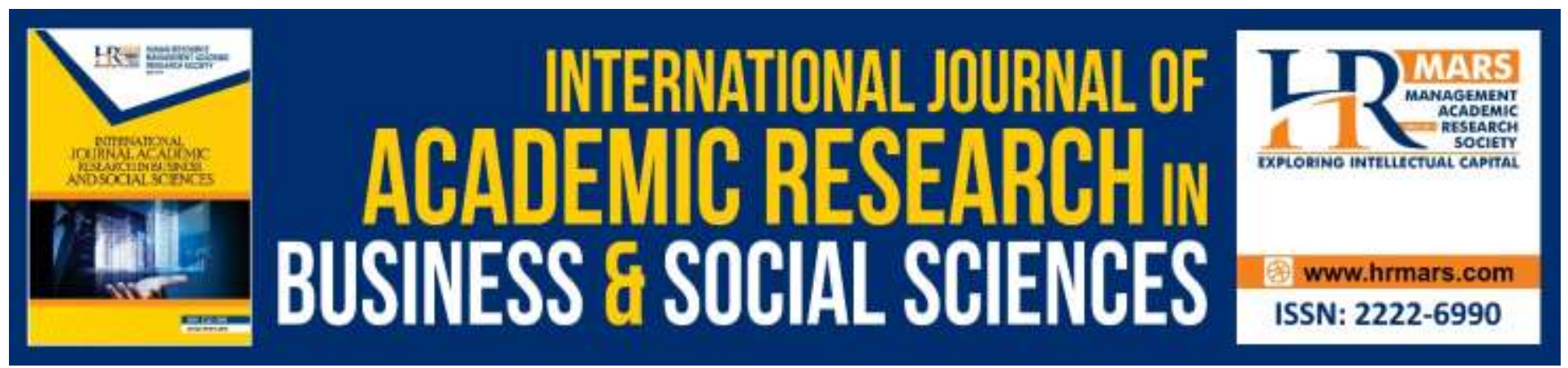

\title{
Impact of Total Quality Management on Business Value Excellence: A Field Study
}

Ghassan Issa Alomari, Imad Al Muala, Mohammed Ali Al-Qudah, Nemeh Abbas Al-Khafaji

To Link this Article: http://dx.doi.org/10.6007/IJARBSS/v10-i2/6947

DOI:10.6007/IJARBSS/v10-i2/6947

Received: 23 January 2020, Revised: 02 February 2020, Accepted: 15 February 2020

Published Online: 26 February 2020

In-Text Citation: (Alomari et al., 2020)

To Cite this Article: Alomari, G. I., Muala, I. Al, Al-Qudah, M. A., \& Al-Khafaji, N. A. (2020). Impact of Total Quality Management on Business Value Excellence: A Field Study. International Journal of Academic Research in Business and Social Sciences, 10(2), 522-538.

\section{Copyright: (C) 2020 The Author(s)}

Published by Human Resource Management Academic Research Society (www.hrmars.com)

This article is published under the Creative Commons Attribution (CC BY 4.0) license. Anyone may reproduce, distribute, translate and create derivative works of this article (for both commercial and non-commercial purposes), subject to full attribution to the original publication and authors. The full terms of this license may be seen

at: http://creativecommons.org/licences/by/4.0/legalcode

Vol. 10, No. 2, 2020, Pg. 522 - 538

http://hrmars.com/index.php/pages/detail/IJARBSS

JOURNAL HOMEPAGE

Full Terms \& Conditions of access and use can be found at http://hrmars.com/index.php/pages/detail/publication-ethics 


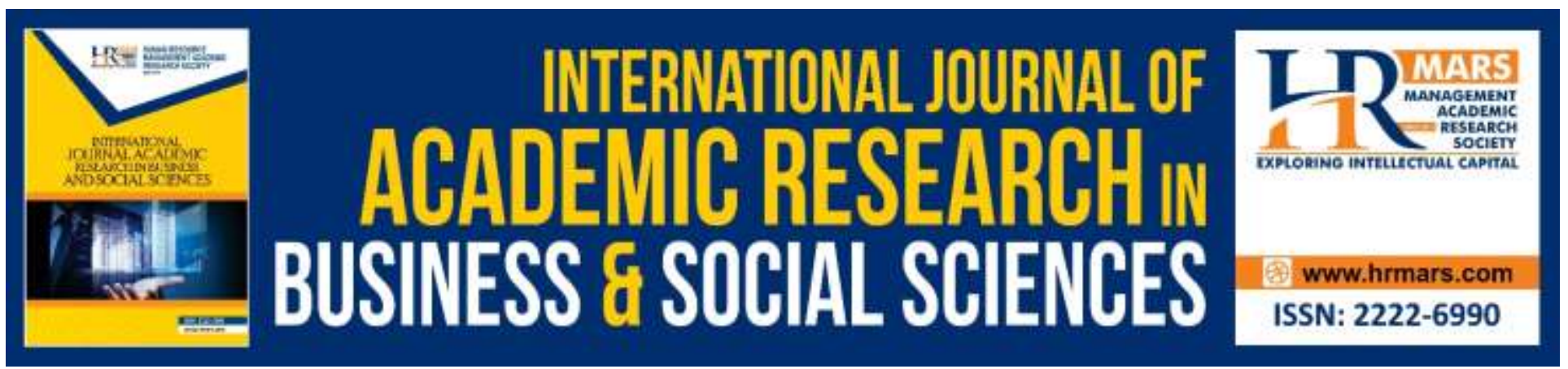

\title{
Impact of Total Quality Management On Business Value Excellence: A Field Study
}

\author{
Ghassan Issa Alomari ${ }^{1}$, Imad Al Muala², Mohammed Ali Al-Qudah³, \\ Nemeh Abbas Al-Khafaji ${ }^{4}$ \\ ${ }^{1,2}$ Amman Arab University, ${ }^{3} \mathrm{Al}$ Shariqa Police Academy, ${ }^{4}$ Isra University \\ Email: ghassanomari@aau.edu.jo,almuala@aau.edu.jo,qudah962@gmail.com, \\ neamaabass@yahoo.com
}

\begin{abstract}
This study aimed to analyse the elements of total quality management (TQM) and its impact on achieving business value excellence. The study aimed to determine the level of managers' awareness regarding various elements of TQM. The study population consists of 14 Royal Medical Services (RMS) hospitals in Jordan. The sample consisted of 31 respondents who are working in a quality department in RMS.

The study used the analytical descriptive research method and a questionnaire as a tool for data collection. The collected data were analysed using Statistical Package for the Social Sciences via descriptive and simple regression analysis.

The study recommended RMS to sustain the implication of TQM by using empowerment, customer focus and scientific approach to decision making and problem solving. In addition, the study embraced the possibility of future improvements to use measurements in determining the level of managers' awareness of TQM and business value excellence.
\end{abstract}

Keywords: Total Quality Elements, Business Value Excellence, Royal Medical Services Hospitals, Jordan

\section{Introduction}

Quality is one of the most critical success factors of business success and sustainability. Recent researchers are interested in investigating different contributions of quality in the field of management. Various interpretations were introduced for quality in accordance with marketing, operations, supply chain, benchmarking, process re-engineering, process management, total quality management (TQM) and its various systems (Al-Azzawi, 2010). Several researchers have addressed the concept of business value excellence by referring to high-performing organisations. These studies include Kermally (2002), Harvey and Brown (2001) and Ali, M., and Heller, R. (2001). Certain studies found a number of variables that contribute to the addition of high business value, including cost 
reduction, quality improvement, customer satisfaction, risk taking, upgrade experience level and technological support of rapid movement towards new technology (Alomri, 2004). The present study focused on TQM in achieving excellent service in the health sector in Jordan, particularly in the Royal Medical Services (RMS). Business excellence has been a top priority of organisations since the early 1980s. TQM was followed by many scientific and practical efforts that resulted in the creation of renowned models of excellence, such as the European Excellence Model for Quality Management (EFQM). Excellence in business value has been one aspect of this distinction. The researchers expect that studies analysing the impact of total quality (TQ) elements in business value excellence are limited. Thus, the scholars were motivated to discuss the elements and aspects of excellence and analyse the nature of the expected impact between them.

\section{Problem}

Using TQ is a common problem in all organisations. Many organisations seek to upgrade the level of TQM in different operations by maintaining and sustaining it to adapt to dynamic business environments. However, most of the efforts of researchers and consultants have focused on quality, which has motivated researchers to adopt a TQ approach. In addition, the organisation under research has a rich experience in the field of TQM. The organisation is active in the Jordanian economy and plays a distinctive role in providing comprehensive and diversified health care to serve clients. Thus, the process of integrating the conceptual construction of TQM with practical architecture requires careful reflection of bridging this gap in the manner of interaction, containment and participation. Therefore, researchers expect that business value excellence is only an indicator of managers' awareness of the elements of TQM.

The purpose of the study is to analyse the elements of TQM and its impact on the business value excellence in RMS hospitals. Therefore, the following hypotheses can be formulated:

The main first hypothesis is that no statistically significant effect is observed $(a=0.05)$.

1.1 No statistically significant effect $(a=0.05)$ of the TQ elements in the business value excellence of service at RMS hospitals is observed.

1.2 No statistically significant effect $(a=0.05)$ of the TQ elements in the business value excellence of the RMS hospitals is observed.

1.3 No statistically significant effect $(a=0.05)$ of the TQ elements in the business value excellence of reduction of cost in the RMS hospitals is observed.

\section{Conceptual Model}

The conceptual model supposes that TQM elements have an impact on business value excellence. The excellence of high service, high quality and low cost as a dependent variable only answers the questions of managers' awareness, such as combined and individual quality elements. These elements formed the independent variable as provided by Goetsch, D. L., and Davis, S. B. (2014) and as shown in Figure 1. 
Figure(1)

Study Model

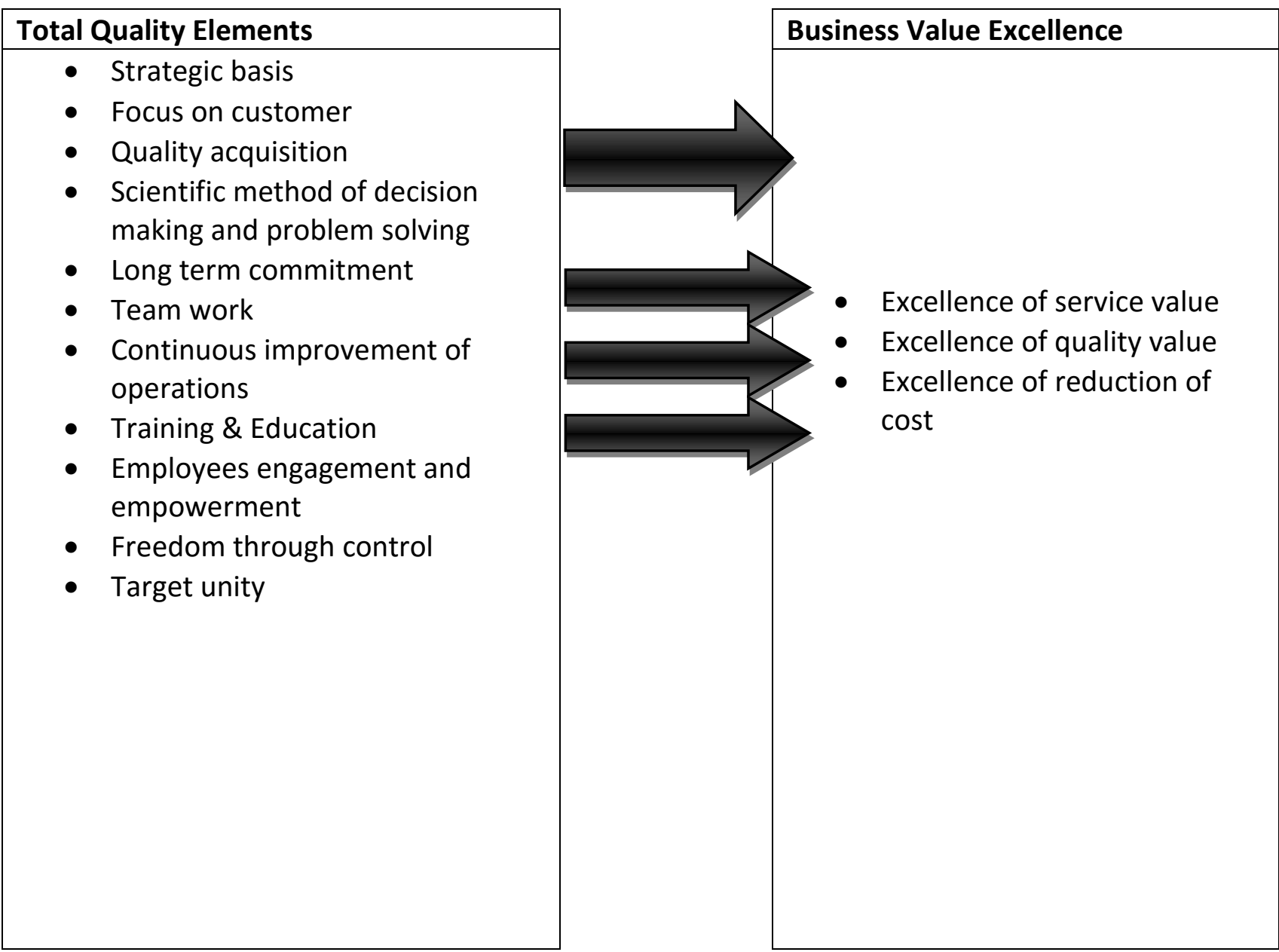

- Goetsch \& Davis (2014). Quality management for organizational excellence.

\section{Theoretical Framework and Previous Studies}

\section{Total Quality Elements}

Total quality is one of the most modern management trends that emerged at the beginning of the 1980s. TQM was first implemented in 1985 in the United States because of the increasing intensity of global competition and the superiority of Japanese industries. TQM was implemented due to its sweep to world markets, especially the under developed countries and the loss of large shares of American and European companies (Tallha, 2004: 15). The concept of TQ can be defined as 'a comprehensive process for the development of the organisation and its transition from the initial application of quality to the stage of distinction and excellence'.

The British Standards Institute (2000) defines TQM as a management philosophy that encompasses all of an organisation's activities in which the needs and expectations of customers and a community are met. Furthermore, the objectives of an organisation are achieved in the most 
efficient and inexpensive way by optimising the capacity of all employees with continuous motivation for development and improvement (AL Azzawi, 2010, 29).

The concept of TQM has four stages, namely, inspection, quality control, quality assurance and TQM. The development of the concept of strategic quality management is an extension of the concept of TQM and is based on the construction of a comprehensive quality system. Since the 1990s, TQM has required a unique type of leadership. Productivity is determined in the light of human performance through innovation, problem solving, teamwork and contribution to added value, sincerity and commitment to continuous improvement.

In the context of TQM, leaders are expected to exert additional work, presence, vigilance and awareness because of their role in motivating others to excel in business. Leaders are required to focus more on organisational performance than on their individual responsibilities. Leadership in the context of TQM is not a tool for control but for the empowerment and development of employees.

The main components of effective quality leadership are as follows: demonstrating vision and strategic choice that define future aspirations and expectations; communicating the organisation's vision and encouraging commitment to the organisation to ensure effective partnership; fostering a culture that focuses on processes rather than individuals; considering employees a source of power by investing in their training and development; encouraging employees' participation in decision making to encourage their innovation and creativity; providing rewards, recognition and performance management to ensure that requirements will be met at a high quality; developing strong partnerships with customers, suppliers and overseas ambassadors to promote the organisation and emphasise its community responsibility; training leaders in the organisation through employee development efforts; and upholding an organisational atmosphere of simplicity, compassion and constructive feedback (Zaire, 2005: 93-99). Goetsch and Davis (2014) described that the trends that shape and drive quality management in the 21st century is the increase of global competition that requires continuous differentiation between organisations. In the same line, customer expectations increase. Customers are no longer satisfied by the quality of products only. They seek to distinguish products or services by their companies' efforts on social responsibility. Moreover, confronting economic pressure in the global market causes intense competition and major changes. As a result, customers are now looking to reduce the cost of services in return for increasing their quality and excellence. Finally, management has new approaches, wherein successful companies in the labour market learn lessons in managing their budgets while leading their employees and they are inseparable.

\section{Business Value Excellence \\ Excellence of Service Value}

Health and safety organisations use the core principles of TQM. Its methods and tools are used to promote a systematic approach that combines knowledge, skills and processes to adopt best practices and achieve excellence in service improvement. The methodological approach consists of three components as follows: a comprehensive model to measure performance that shows the extent to which an organisation succeeds in meeting the needs and expectations of stakeholders, the quantitative measurement of these needs and expectations and the planning cycle (work, assertion and performance). A cycle takes place at all levels and across all processes for continuous improvement and excellence in service delivery. The use of self-assessment systems for measuring 
INTERNATIONAL JOURNAL OF ACADEMIC RESEARCH IN BUSINESS AND SOCIAL SCIENCES

Vol. 10, No. 2, Feb, 2020, E-ISSN: 2222-6990 @ 2020 HRMARS

performance is evidenced by the EFQM and the Malcom Baldrige National Quality Award Model (Zaire, 2007).

\section{Excellence of Quality Value}

Quality measurement in health care has various approaches including a structural approach that focuses on the availability of specialties, tools and number of patients; a process approach that focuses on converting inputs into outputs; and the final output approach that focuses on the service provided to patient and patient satisfaction. The final output approach is considered the best approach, focusing on the quality of health care and service provided to patients. Quality measurement consists of five dimensions to measure the gap between expectations and actual performance: tangibility (renewal, attraction and appearance), reliability (meeting the obligations of a health organisation and seeking to provide timely service and the necessary speed and accuracy in work), response (serving the immediate patient promptly), safety (an organisation's keenness to gain the trust of a patient and his feeling of safety during the service) and finally, sympathy (providing care to patients and understanding their needs and circumstances) (Bani hamdan and Zboun, 2015). Guoily (2013: 543) emphasised the multiple entry points for quality including the basis of excellence, product specifications, the beneficiary and value, which is excellence at the lowest prices. In addition, the application of quality in hospitals has benefits, that is, facing multiple challenges including increased costs, quality of care provided, patient satisfaction and encouragement of employees.

\section{Excellence of Reduction of Cost}

Costing quality is a measurement method to justify quality improvement efforts and is also an indicator used by international organisations to measure internal quality performance. Crosby, one of the influential scholars on quality, called quality management measurement the foundation of quality management. Furthermore, Crosby emphasised that these costs can and should be measured to decrease the cost of quality, thereby saving up to $20 \%$ of the profit (Zairi, 2007: 21). Tidd (2000: 20) emphasised that focusing on and improving the process of innovation contributes to cost reduction.

\section{Literature Review}

Shabir et al., (2016) study, Measuring Patients' Healthcare Service Quality Perceptions, Satisfaction and Loyalty in Public and Private Sector Hospitals in Pakistan, aimed to measure patients' perceptions of the quality of health care services, satisfaction and loyalty to the government and private hospitals in Pakistan. The study found that patients' awareness of the quality of the health care services provided to them has a positive effect on loyalty to the hospital. Patient satisfaction mediates the relationship between the quality of the health care service provided and loyalty to the hospital. The finding of the study also showed statistically significant differences between the quality of health care services provided by private hospitals and public hospitals. Ajmal et al. (2016) studied TQM practices in the public sector as a case of Finnish healthcare organisations. The study discussed the evolution and the stages and principles of TQM in the health care organisations in Finland and how they can be applied distinctly in the public sector. The study used the qualitative research method. The data were collected by using a structured interview and the auditing of documentation of TQM as a case study. The study concluded that attention must be given to the critical role of stakeholders in the application of TQM from a strategic perspective. 
Rane, Sheppy, and Mclntosh (2015) study, Conceptual Framework for Quality Management of Emergency Medical Systems in India using Lean Thinking-A Doctor's Perspective, aimed to demonstrate the need of emergency departments in Indian hospitals to keep up with international standards. The study was a conceptual framework for quality management to improve health care specifically in rural areas in India. The study concluded with a medical perspective that requires the application of TQM in emergency medical systems, which help in patient satisfaction and in improving the services provided to them. This study is in line with Lean's (Just in Time) service applied by it in its quality management framework and supply. Tsai et al., (2015) noted that hospital boards and management practices are strongly related to hospital performance on clinical quality metrics. Their study aimed to identify the dynamics of the councils in British and American hospitals by investigating the relationship between hospital councils and management practices. This relationship was associated with a strong positive relationship with hospital performance when evaluated by clinical quality measures. The study found that management practices are effective in providing high-quality healthcare and that superior performance in hospitals has been achieved by frontline staff in the hospital management. The study confirmed that hospitals that used clinical quality measures were the most effective in superior performance, thus contributing to the achievement of objectives and operations. Chukmaitov, Harless, Bazzoli, Carretta, and Siangphoe (2015) studied delivery system characteristics and their association with quality and costs of care: implications for accountable care organisations. The study aimed at investigating the characteristics of the delivery system and its relation to quality and costs of care: the effects of responsible care organisation. The study was conducted on a hospital group in Florida (2006-2009) that benefited from central information systems. This study has been subjected to responsible care programmes (ACOs) by linking databases and patient records. The study found that hospitals that have been involved in electronic connectivity have improved the quality of their health care services, although this effect has not been reflected in cost reduction. However, the provision of quality services is considered an effective strategy to improve the quality of health care in the future.

Aichi (2013) conducted a field study on the 'diagnosis of the reality of the application of TQM in Algerian hospitals' at the Bashir Ben Nasser Hospital in Biskra, Algeria. The study aimed at diagnosing the real application of TQM in the hospital. A random sample of 203 workers was selected from the hospital. The data were analysed, and the results reached the most significant results. The hospital staff are fully aware of the importance of implementing TQM according to the four variables of TQM (focus on patients, continuous improvement, senior management commitment and employee involvement). Certain differences in employees' attitudes in respect of their understanding of the importance of applying TQM due to demographic variables (gender, age, level of education, type of work and experience) are observed.

\section{Methodology}

The present study adopts the analytical descriptive method. This approach focuses on the level of awareness of managers of the elements of the TQ of an organisation. This approach also focused on the business value excellence of its work on the basis of the results of their responses to the questionnaire items, which indicate the dimensions of the variables of the study model. The analytical side focused on the use of the results of the inference statistics to verify the acceptability or refusal 
INTERNATIONAL JOURNAL OF ACADEMIC RESEARCH IN BUSINESS AND SOCIAL SCIENCES Vol. 10, No. 2, Feb, 2020, E-ISSN: 2222-6990 @ 2020 HRMARS

of the hypotheses included the attempt to detect the impact of the elements of the TQ in the business value excellence. The present study used multiple regressions to measure the validity of the study model and its suitability to explain the impact of TQM elements on the excellence of service values, quality and cost.

\section{Sampling}

The RMS hospitals formed the study population for this study population and its sample. The number of hospitals in the population is 14 . The study sample consisted of 35 . All employees of the five quality departments are located in the centre of the Medical City. After retrieving the questionnaires, the number of valid questionnaires for the analysis is 31 respondents including managers, deputies, assistants, heads of departments and those working in the supporting medical professions in the hospitals indicated in the quality departments by $89 \%$. The selection was justified due to excellent performance of these hospitals in the Jordanian health sector. Their contribution to the provision of comprehensive health care and support for medical tourism in the Jordanian health sector represent high economic impact in Jordan.

\section{Measure and Technique}

The present study has designed a questionnaire as a tool of data collection, which has been adapted from Goetsch and Davis (2014). Respondents were asked for a response for each statement in the questionnaire according to a five-point Likert scale, which ranges from 'totally disagree' (1) to 'totally agree' (5). The values of the Cronbach's alpha coefficient have been calculated as shown in Table (1) to calculate the stability of the questionnaire as a tool to measure the variables of the study model.

Table (1)

Cronbach's alpha coefficient of variables of study model

\begin{tabular}{|l|l|}
\hline Variables of study model & Cronbach's alpha value \% \\
\hline Total quality elements items & 0.92 \\
\hline Business value excellence items & 0.85 \\
\hline All items & 0.93 \\
\hline
\end{tabular}

The values of the Cronbach's alpha coefficient in Table (1) show a high internal consistency. The quality elements and the excellence of business values were greater than the standard 0.70 . This result indicates that the questionnaire can be used as a data collection and analysis tool according to Hair et al., (2006). The questionnaire was distributed, and the data collected have a $100 \%$ response rate. However, only $98 \%$ were completed and suitable for analysis.

\section{Data Analysis}

The first question in the study problem can be answered by using the mean values and the standard deviations of the TQ elements as shown in Table (2). The findings below lead to the fact that the issue of TQ and its elements fall within the focus of health quality assurance departments in the hospitals of the study population (4.09-3.68). This trend is reinforced by the state of diversity in the characteristics and priority of the sampling unit of these departments in RMS hospitals. 
INTERNATIONAL JOURNAL OF ACADEMIC RESEARCH IN BUSINESS AND SOCIAL SCIENCES Vol. 10, No. 2, Feb, 2020, E-ISSN: 2222-6990 @ 2020 HRMARS

Table (2): Values of means and standard deviations of the total quality elements in descending order

\begin{tabular}{|l|c|c|}
\hline Total Quality elements & Mean & Standard Deviations \\
\hline Training and education & 4.09 & 0.58 \\
\hline Strategic basis & 4.00 & 0.63 \\
\hline Focus on customer & 3.99 & 0.81 \\
\hline Target unity & 3.95 & 0.50 \\
\hline Teamwork & 3.89 & 0.61 \\
\hline Continuous improvement of operations & 3.88 & 0.70 \\
\hline Freedom through control & 3.80 & 0.67 \\
\hline Long term commitment & 3.77 & 0.57 \\
\hline Scientific approach of decision making & 3.77 & 0.70 \\
and problem solving & & 0.76 \\
\hline Acquisition of quality & 3.73 & 0.73 \\
\hline Employees engagement & 3.68 & 0.53 \\
\hline Total & 3.87 & \\
\hline
\end{tabular}

The second question can be answered in the study problem by using the values of means and the standard deviations of excellence business value as shown in Table (3). The results of mean and standard deviation indicated a significant increase in the level of service, quality and cost excellence. In addition, the results indicated the approaching level of managers' awareness of the excellence of business value in its dimensions.

Table (3)

The mean and standard deviations of excellence business value as arranged in descending order

\begin{tabular}{|l|c|c|}
\hline Business value excellence & Arithmetic mean & Standard Deviations \\
\hline Excellence of service value & 3.91 & 0.49 \\
\hline Excellence of quality value & 3.85 & 0.62 \\
\hline Excellence of cost reduction & 3.66 & 0.78 \\
\hline Total & 3.81 & 0.54 \\
\hline
\end{tabular}

Table (3) shows that the priority was in favour of the excellence of the service value (3.91). The preliminary results of the study indicate that a state of awareness of the excellence of business value at quality assurance departments exists in RMS hospitals. This result implies a significant contribution to the elements of TQ by achieving excellence within the framework of leadership and sustainable excellence.

\section{Test of Hypotheses}

The main hypothesis is 'no significant impact of TQ elements is observed in the excellence business value in RMS hospitals'.

The main hypothesis was tested through a (simple) regression. Table (4) shows the results of the test as follows: 
INTERNATIONAL JOURNAL OF ACADEMIC RESEARCH IN BUSINESS AND SOCIAL SCIENCES Vol. 10, No. 2, Feb, 2020, E-ISSN: 2222-6990 @ 2020 HRMARS

Table 4 shows the summary of the regression analysis where the positive correlation coefficient is shown as $R=0.743$. The result indicates a positive and strong relationship between the elements of the TQ and the excellence business value in RMS hospitals. The value of $R^{2}=0.553$ indicates the ability of TQ elements to predict excellence business value in RMS hospitals.

Table 4 shows the regression variable analysis where $F=35.819$, and the value of $\operatorname{Siq}=0.000$ is less than $\alpha=0.05$. The value of the statistical significance level means rejecting the main null hypothesis and accepting the alternative hypothesis. The alternative hypothesis states that 'a statistically significant impact of the TQ elements at $(\alpha=0.05)$ on the excellence business value is observed in RMS hospitals'.

\section{Table (4)}

Result of Regression Analysis

Coefficients

\begin{tabular}{|c|c|c|c|c|c|c|}
\hline \multirow{2}{*}{\multicolumn{2}{|c|}{ Model }} & \multicolumn{2}{|c|}{$\begin{array}{c}\text { Unstandardized } \\
\text { Coefficients }\end{array}$} & \multirow{2}{*}{$\begin{array}{c}\text { Standardized } \\
\text { Coefficients } \\
\text { Beta }\end{array}$} & \multirow[b]{2}{*}{$\mathrm{T}$} & \multirow[b]{2}{*}{ Sig. } \\
\hline & & B & Std. Error & & & \\
\hline \multirow[t]{2}{*}{1} & (Constant) & .707 & .522 & & 1.355 & .186 \\
\hline & $\begin{array}{r}\text { Total quality } \\
\text { factors }\end{array}$ & .801 & .134 & .743 & 5.985 & .000 \\
\hline
\end{tabular}

a. Dependent Variable: excellence business value

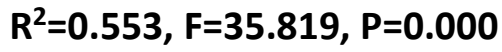

Table (6) shows the result of the regression analysis and through the values of a and $\beta$. The formula of the prediction equation can be illustrated as follows: $Y=\alpha+b 1 \times 1$.

Excellence business value $=0.707+0.801 \times$ total quality elements.

The TQ elements in the medical services hospitals must be increased by the quantities in the equation to increase excellence business value. This result is confirmed by the value of beta $=0.743$, which is equal to the value of the correlation coefficient between the two variables, which is a positive and strong value.

\section{First Sub-Hypothesis}

1.1 'No statistically significant impact of TQ elements in the excellence of service value is observed in RMS hospitals'.

The first sub-hypothesis was tested by using the stepwise regression method. Table 5 shows the summary of the multiple regression analysis where the correlation coefficient value is shown as $R=$ 0.565 . The result indicates a positive relationship between the TQ elements through control, and the value of service in RMS hospitals is indicated by the value of $R^{2}=0.319$.

Table 5 shows the analysis of the stepwise multiple regression analysis where $F=13.58$ indicates that the value of $\operatorname{Sig}=0.001$ is less than $\alpha=0.05$, the value of the statistical significance level. This result means the rejection of first sub-null hypothesis and acceptance of the alternative hypothesis which states that 'a statistical significance of the element of freedom by controlling the excellence 
INTERNATIONAL JOURNAL OF ACADEMIC RESEARCH IN BUSINESS AND SOCIAL SCIENCES Vol. 10, No. 2, Feb, 2020, E-ISSN: 2222-6990 (C) 2020 HRMARS

of service value is observed in RMS hospitals, whereas the rest of the other elements of the regression prediction equation were excluded because their significance values are greater than (0.05.)'.

Table (5): Result of Multiple Regression Analysis

Coefficients $^{\text {a }}$

\begin{tabular}{|ll|c|c|c|c|c|}
\hline \multirow{2}{*}{ Model } & \multicolumn{2}{|c|}{$\begin{array}{c}\text { Unstandardized } \\
\text { Coefficients }\end{array}$} & $\begin{array}{c}\text { Standardized } \\
\text { Coefficients }\end{array}$ & \multirow{2}{*}{} & \\
\cline { 2 - 4 } & $\mathrm{B}$ & Std. Error & Beta & $\mathrm{T}$ & Sig. \\
\hline 1 & (Constant) & 2.321 & .439 & & 5.290 & .000 \\
& Control free & .420 & .114 & .565 & 3.685 & .001 \\
\hline
\end{tabular}

a. Dependent Variable: Business value of service $R^{2}=0.319, F=13.578, P=0.001$

Table (5) shows the result of the multi-regression analysis and through the values of a and $\beta$, the equation of the prediction equation can be illustrated as follows: $Y=a+b 1 \times 1$.

Business value service $=2.321+0.420 \times$ element of freedom through control.

Increasing the element of freedom through the control in the hospitals of medical services in the quantities contained in the equation is necessary to increase the value of the service excellence of one unit. This finding confirms that the value of beta $=0.655$, which is equal to the value of correlation coefficient between the two variables, is positive and falls in the medium value level.

\section{Second Sub-hypothesis}

1.2 'No statistical significant impact of TQ elements is observed in the quality of the RMS hospitals'.

Table (6): Multiple regression summary

\begin{tabular}{|l|l|r|r|rr|}
\hline Model & $\mathrm{R}$ & $\begin{array}{c}\mathrm{R} \\
\text { Square }\end{array}$ & $\begin{array}{c}\text { Adjusted R } \\
\text { Square }\end{array}$ & \multicolumn{2}{|c|}{ Std. Error of the Estimate } \\
\hline 1 & $.640^{\mathrm{a}}$ & .409 & .389 & .484 \\
\hline 2 & $.761^{\mathrm{b}}$ & .579 & .548 & .416 \\
\hline 3 & $.801^{\mathrm{c}}$ & .642 & .602 & .391 \\
\hline
\end{tabular}

a. Predictors: (Constant), empowerment

b. Predictors: (Constant), empowerment, customer

c. Predictors: (Constant), empowerment, customer, scientific

The second sub-hypothesis was tested by using the stepwise multiple regression. 
INTERNATIONAL JOURNAL OF ACADEMIC RESEARCH IN BUSINESS AND SOCIAL SCIENCES Vol. 10, No. 2, Feb, 2020, E-ISSN: 2222-6990 (C) 2020 HRMARS

Table (7)

Multiple regression variance analysis

ANOVA ${ }^{d}$

\begin{tabular}{|rr|c|c|c|c|c|}
\hline \multicolumn{2}{|l|}{ Model } & Sum of & & & & \\
& & Squares & Df & Mean Square & $\mathrm{F}$ & Sig. \\
\hline 1 & Regression & 4.717 & 1 & 4.717 & 20.110 & $.000^{\mathrm{a}}$ \\
& Residual & 6.802 & 29 & .235 & & \\
& Total & 11.520 & 30 & & & $.000^{\mathrm{b}}$ \\
\hline 2 & Regression & 6.665 & 2 & 3.332 & 19.219 & \\
& Residual & 4.855 & 28 & .173 & & $.000^{\mathrm{c}}$ \\
& Total & 11.520 & 30 & & & \\
\hline 3 & Regression & 7.397 & 3 & 2.466 & 16.148 & \\
& Residual & 4.123 & 27 & .153 & & \\
& Total & 11.520 & 30 & & & \\
\end{tabular}

a. Predictors: (Constant), empowerment

b. Predictors: (Constant), empowerment, customer

c. Predictors: (Constant), empowerment, customer, scientific

d. Dependent Variable: excellence value of quality

The results shown in Table (6) indicate the entry of three elements of the TQ elements (customer focus, employee engagement and empowerment, scientific method of decision-making and problem solving) in the RMS hospitals. $R$-values respectively refer to $0.640 \mathrm{a}, 0.761 \mathrm{~b}$ and $0.801 \mathrm{c}$, that is, a strong and positive relationship between these variables and the dependent variable. $R^{2}$ values $(0.409,0.599$ and 0.642$)$ were shown, and the rest were attributed to other factors.

Table (7) shows the regression analysis. $F$ values are 20.110, 19.219 and 16.148 , and all Sig $=0.000$ values, which is less than $a=0.05$, the value of the statistical significance level, which means rejecting the main null hypothesis and accepting the alternative hypothesis. The elements of TQ (empowerment, customer focus, scientific approach to decision making and problem solving) have a significant impact on the quality of excellence in RMS hospitals. The rest of the elements are influential but not significant; hence, they were excluded from the regression equation. 
INTERNATIONAL JOURNAL OF ACADEMIC RESEARCH IN BUSINESS AND SOCIAL SCIENCES

Vol. 10, No. 2, Feb, 2020, E-ISSN: 2222-6990 @ 2020 HRMARS

\section{Table (8): Result of Multiple Regression Analysis}

\section{Coefficients $^{\text {a }}$}

\begin{tabular}{|c|c|c|c|c|c|c|}
\hline \multirow{2}{*}{\multicolumn{2}{|c|}{ Model }} & \multicolumn{2}{|c|}{$\begin{array}{c}\text { Unstandardized } \\
\text { Coefficients }\end{array}$} & \multirow{2}{*}{$\begin{array}{c}\text { Standardized } \\
\text { Coefficients }\end{array}$} & \multirow[b]{2}{*}{$\mathrm{T}$} & \multirow[b]{2}{*}{ Sig. } \\
\hline & & B & Std. Error & & & \\
\hline \multirow[t]{2}{*}{1} & (Constant) & 1.859 & .452 & & 4.112 & .000 \\
\hline & Empowerment & .541 & .121 & .640 & 4.484 & .000 \\
\hline \multirow[t]{3}{*}{2} & (Constant) & .879 & .487 & & 1.806 & .082 \\
\hline & Empowerment & .459 & .107 & .543 & 4.306 & .000 \\
\hline & Customer & .322 & .096 & .422 & 3.351 & .002 \\
\hline \multirow[t]{4}{*}{3} & (Constant) & 1.083 & .466 & & 2.323 & .028 \\
\hline & Empowerment & .591 & .117 & 699 & 5.060 & .000 \\
\hline & Customer & .446 & .106 & .586 & 4.189 & .000 \\
\hline & Scientific & -.314 & .143 & -.355 & -2.190 & .037 \\
\hline
\end{tabular}

a. Dependent Variable: excellence business value of quality

Table (8) shows the result of the analysis of the multiple regression and through the values of $a$ and b. The formula of the prediction equation can be illustrated as follows:

$Y=a+b 1 \times 1+b 2 \times 2+b 3 \times 3$. (1)

The business value of quality $=1.859+0.541 \times$ engaging and empowering employees $+0.322 \times$ customer focus $+0.314 \times$ the scientific input to decision-making and problem solving.

Increasing the elements of engagement and empowerment of employees, focus on customers, and scientific input in decision-making and problem solving in medical services hospitals with the values in the equation (0.355) is necessary. The values in the equation (0.355) are equal to the value of correlation coefficients between the variables. The objective is to increase the value of the quality of one unit.

\section{Sub-hypothesis III}

1.3 'A statistically significant impact of TQ elements in excess of cost reduction is observed in RMS hospitals'.

The second sub-hypothesis was tested by using the multi-gradient regression. The results of Table (9) indicate that three elements of TQM (quality acquisition, target unit, training and learning) entered the moral impact of cost overruns in RMS hospitals. $R$ values indicated (708a, $0.773 \mathrm{~b}$ and $0.817 \mathrm{c}$ ) strong and positive relationships between these variables and the dependent variable. $R^{2}$ values (502, 0.598 and 0.668 ) were shown, and the rest were attributed to other factors. 
INTERNATIONAL JOURNAL OF ACADEMIC RESEARCH IN BUSINESS AND SOCIAL SCIENCES Vol. 10, No. 2, Feb, 2020, E-ISSN: 2222-6990 @ 2020 HRMARS

Table (9): Summary of Regression Results

\begin{tabular}{|l|l|r|r|rr|}
\hline Model & & \multicolumn{1}{|c|}{ R } & $\begin{array}{c}\text { Adjuste } \\
\mathrm{d} R \\
\text { Square }\end{array}$ & \multicolumn{2}{|c|}{ Std. Error of the Estimate } \\
\hline 1 & $\mathrm{R}$ & Square & \multicolumn{1}{|c|}{ Squar } & .561 \\
\hline 2 & $.708^{\mathrm{a}}$ & .502 & .484 & & .513 \\
\hline 3 & $.773^{\mathrm{b}}$ & .598 & .569 & .475 \\
\hline
\end{tabular}
a. Predictors: (Constant), quality ac
b. Predictors: (Constant), quality ac, goal unit
c. Predictors: (Constant), quality ac, goal unit, training, learn

Table 10 shows the analysis of the multiple regression variance, where $F$ values are 29.187, 20.830 and 18.117, and that all Sig $=0.000$ values are less than $a=0.05$. The value of the statistical significance level means rejecting the main null hypothesis and accepting the alternative hypothesis for the elements of TQ (quality acquisition, target unit, training and learning) in the superiority of cost reduction in RMS hospitals. The rest of the elements have an impact on cost reduction but not significant; hence, they were excluded from the regression prediction equation.

Table (10): Multiple Regression Variance Analysis

ANOVA $^{d}$

\begin{tabular}{|c|c|c|c|c|c|c|}
\hline \multicolumn{2}{|c|}{ Model } & $\begin{array}{l}\text { Sum of } \\
\text { Squares }\end{array}$ & Df & $\begin{array}{l}\text { Mean } \\
\text { Square }\end{array}$ & $F$ & Sig. \\
\hline \multirow[t]{3}{*}{1} & Regression & 9.194 & 1 & 9.194 & 29.187 & $.000^{\mathrm{a}}$ \\
\hline & Residual & 9.135 & 29 & .315 & & \\
\hline & Total & 18.330 & 30 & & & \\
\hline \multirow[t]{3}{*}{2} & Regression & 10.962 & 2 & 5.481 & 20.830 & $.000^{b}$ \\
\hline & Residual & 7.368 & 28 & .263 & & \\
\hline & Total & 18.330 & 30 & & & \\
\hline \multirow[t]{3}{*}{3} & Regression & 12.246 & 3 & 4.082 & 18.117 & $.000^{c}$ \\
\hline & Residual & 6.084 & 27 & .225 & & \\
\hline & Total & 18.330 & 30 & & & \\
\hline
\end{tabular}

a. Predictors: (Constant), quality ac

b. Predictors: (Constant), quality ac, goal unit

c. Predictors: (Constant), quality ac, goal unit, traning learn

d. Dependent Variable: super cost

Table (11) shows the result of the analysis of the multiple regression and through the values of $a$ and b. The formula of the prediction equation can be illustrated as follows:

$Y=a+b 1 \times 1+b 2 \times 2+b 3 \times 3 .(2)$

Excellence cost reduction $=0.928+0.731 \times$ quality acquisition $+0.299 \times$ objective unit $+-421 \times$ training and learning. 
INTERNATIONAL JOURNAL OF ACADEMIC RESEARCH IN BUSINESS AND SOCIAL SCIENCES Vol. 10, No. 2, Feb, 2020, E-ISSN: 2222-6990 @ 2020 HRMARS

The elements (quality acquisition, target unit, training and learning) in the RMS hospitals must be increased by the values in the equation to increase the value of quality excellence in one unit. This finding is confirmed by the standard beta values $0.708,335$ and 311 among the mentioned variables.

Table (11): Result of Multiple Regression Analysis

Coefficients $^{\text {a }}$

\begin{tabular}{|c|c|c|c|c|c|c|}
\hline \multirow{2}{*}{\multicolumn{2}{|c|}{ Model }} & \multicolumn{2}{|c|}{$\begin{array}{l}\text { Unstandardized } \\
\text { Coefficients }\end{array}$} & \multirow{2}{*}{$\begin{array}{c}\text { Standardized } \\
\text { Coefficients }\end{array}$} & \multirow[b]{2}{*}{$\mathrm{T}$} & \multirow[b]{2}{*}{ Sig. } \\
\hline & & B & Std. Error & & & \\
\hline \multirow[t]{2}{*}{1} & (Constant) & .928 & .515 & & 1.803 & .082 \\
\hline & Quality ac & .731 & .135 & .708 & 5.403 & .000 \\
\hline \multirow[t]{3}{*}{2} & (Constant) & -.675 & .777 & & -.868 & .393 \\
\hline & Quality ac & .601 & .133 & .583 & 4.508 & .000 \\
\hline & Goal unit & .529 & .204 & .335 & 2.592 & .015 \\
\hline \multirow[t]{4}{*}{3} & (Constant) & -.005 & .772 & & -.007 & .995 \\
\hline & Quality ac & .645 & .125 & .625 & 5.171 & .000 \\
\hline & Goal unit & .754 & .211 & .477 & 3.572 & .001 \\
\hline & $\begin{array}{l}\text { Training, } \\
\text { learning }\end{array}$ & -.421 & .176 & -.311 & -2.387 & .024 \\
\hline
\end{tabular}

a. Dependent Variable: excellence cost

\section{Discussion}

Managers of TQMs individually and collectively have a high level of awareness of RMS hospitals, which is consistent with Ajmal, Tuomi, Helo, and Sandhu (2016). A significant increase in the level of service, quality and cost excellence is observed in RMS hospitals. A positive and strong impact of TQ elements in excellence business value is observed in RMS hospitals, which is consistent with the study of Shabbir et al. (2016) in Pakistan and the study of Tsai et al. (2015).

Another finding of the study indicated the significant impact of the element of freedom by controlling the value of service in RMS hospitals. Moreover, the TQ elements (empowerment, customer focus, scientific approach to decision-making and problem solving) in quality excellence in RMS hospitals are in line with the results of Al Aichi (2013) in Algeria. The findings of the study indicated a significant impact of the TQ elements (quality acquisition, target unit, training and learning) in the excellence of cost reduction in RMS hospitals, which is inconsistent with Askare et al. (2015). In addition, the TQ elements may be related to different cultures between Jordan and the United States. Finally, the results of the study showed the significance of the variance analysis and the significance of the coefficients of the TQ elements were strengthened, including the explanatory power of these elements to the expected change in the dimensions of the value of the business. This finding indicates the validity of the idea of the model of the study, which emphasises that the value of business depends on managers' awareness of the elements of the TQ in contemporary business organisations. This study contributed in clarify the importance of TQM on achieving business excellence at service industry, specifically in health care domain. Furthermore, the study enriched the literature of business management through the research model, theoretically and practically. 
INTERNATIONAL JOURNAL OF ACADEMIC RESEARCH IN BUSINESS AND SOCIAL SCIENCES Vol. 10, No. 2, Feb, 2020, E-ISSN: 2222-6990 @ 2020 HRMARS

\section{Recommendations}

Upon the findings of the study and the previous conclusions, the study provides several recommendations. RMS must adopt a sustainability approach in the application of TQM in its various elements with emphasis on the most influential elements, such as empowerment, customer focus and scientific input for decision-making and problem solving. RMS must focus on elements of quality acquisition, unity of purpose, training and learning because of their clear impact on the excellence of cost value. Another recommendation to RMS is to enhance the element of freedom through control because of its clear impact on the excellence of service value. In the same line, RMS must sustain the excellence of the value of the business in terms of quality, service and costs, as the RMS hospitals face increasing competition between hospitals in Jordan, specifically educational and private hospitals. Finally, researchers in field of TQM must take other variables of excellence business value in hospitals, such as investment in information technology, technology support, weighed risk and support scientific research.

\section{References}

Ajmal, M. M., Tuomi, V., Helo, P. T., \& Sandhu, M. A. (2016). TQM Practices in Public Sector: Case of Finnish Healthcare Organizations. International Journal of Information Systems in the Service Sector (IJISSS), 8(1), 34-44.

Al Aichi., A. (2013) Diagnosis of The Reality of The Application of TQM In Algerian Hospitals A Field Study on Beshir Ben Nasser Hospital, Biskra State, Algeria Http://Hdl.Handle.Net/123456789/1292.

Mohammed, A. (2010), Total Quality Management: A Strategic Approach (Ithraa Publishing and Distribution, Amman, Jordan.

Ali, M., \& Heller, R. (2001). Managing for Excellence: The Essential Practical Guide High Performance DK.Pub.

Alomar, I., Ghassan. (2004) Using the Partnering of Information Technology and Knowledge Management To Achieve High Business Value At Jordanian Commercial Banks, Unpublished PhD Dissertation, Amman Arab University For Graduate Studies, Jordan.53-58.

Hamdan., B., Khalid, Al Zboun., Attallah. (2015) Total Quality Management: Concepts and Applications, Dar Al Yazouri Scientific Publishing And Distribution, Amman - Jordan.

Chukmaitov, A., Harless, D. W., Bazzoli, G. J., Carretta, H. J., \& Siangphoe, U. (2015). Delivery system characteristics and their association with quality and costs of care: Implications for accountable care organizations. Health care management review, 40(2), 92-103.

Donald, R. B., \& Harvey, D. (2004). An Experiential approach to organization development. Upper Saddle River., New Jersey.

Foster, S. T. (2001). Managing quality: an integrative approach. New Jersey: Hall, Inc, Upper Saddle River.

Gholami, R., Higón, D. A., \& Emrouznejad, A. (2015). Hospital performance: Efficiency or quality? Can we have both with IT? Expert systems with applications, 42(12), 5390-5400.

Goetsch, D. L., \& Davis, S. B. (2014). Quality Management for Organizational Excellence. Upper Saddle River, Nj: Pearson. 
INTERNATIONAL JOURNAL OF ACADEMIC RESEARCH IN BUSINESS AND SOCIAL SCIENCES

Vol. 10, No. 2, Feb, 2020, E-ISSN: 2222-6990 @ 2020 HRMARS

Goetsch, L., David., And Davis, B., Stanley. (2010), Quality Management for Organizational Excellence, Introduction To Total Quality, Sixth Edition, Pearson Education International, Upper Saddle River, $\mathrm{Nj}$

Hair, Jr., J. F., Black., W. C., Babin., B. J., Anderson., R. E., \& Tatham, L. R. (2006). Multivariant Data Analysis. New Jersey: Pearson International Edition.

Hoffman, T. (2003). How Will You Prove IT Value? Computerworld, 37(1), 26-26.

Jordan, Royal Medical Services Directorate / Al Hussein Medical City, King Abdullah II award For Excellence in Government Performance and Transparency Seventh Session (2014/2015)

Kermally, S. (2002). Effective knowledge management: a best practice blueprint. John Wiley \& Sons, Inc..

Leonard, D., \& McAdam, R. (2004). Total quality management in strategy and operations: dynamic grounded models. Journal of Manufacturing Technology Management, 15(3), 254-266.

Marwick, A. D. (2001). Knowledge management technology. IBM systems journal, 40(4), 814-830.

McGee, J., Wilson, D., \& Thomas, H. (2010). Strategy: Analysis and practice. McGraw-Hill Higher Education.

Peters, T. J., Waterman, R. H., \& Jones, I. (1982). In Search of Excellence: Lessons from America's BestRun Companies

Rane, S., Sheppy, B., \& McIntosh, B. (2015). Conceptual Framework for Quality Management of Emergency Medical Systems in India using Lean Thinking-A Doctor's Perspective. Journal of Global Health Care Systems, 5(3), 1-35.

Shabbir, A., Shahab, M., Shujah, M. (2016). Measuring Patients' Healthcare Service Quality Perceptions, Satisfaction, And Loyalty in Public and Private Sector Hospitals In Pakistan", International Journal Of Quality \& Reliability Management, Vol. 33 Iss: 5, Pp.538 557http://Dx.Doi.Org/10.1108/ljqrm-06-2014-0074

Talha, M. (2004). Total quality management (TQM): an overview. The bottom line, 17(1), 15-19.

Tidd, J. (2002). From Knowledge Management to Strategy Competence: Measurement Technological Market and Organizational Innovation, London, Empirical College Press.

Tsai, T. C., Jha, A. K., Gawande, A. A., Huckman, R. S., Bloom, N., \& Sadun, R. (2015). Hospital board and management practices are strongly related to hospital performance on clinical quality metrics. Health affairs, 34(8), 1304-1311.

Mohamed, Z., Kajun, A. (2005). Best Practices: Organizational Excellence, European Center for Total Quality Bradford University, School of Management, Mohammed Noir Translation. E-Tqm Publishing House, Dubai, United Arab Emirates.

Zairi, M. (2007). Excellence in Performance: A Practical Guide, Translation by Hani William, E-Tqm Publishing House, Dubai, United Arab Emirates. 